\title{
Pendidikan Islam di Tengah Pandemi Covid-19: Upaya Membangun Empati Warga Sekolah
}

\section{Islamic Education During Pandemic Covid19: Efforts to Build Sense of Emphaty}

Received: 16-07-2020; Revised: 16-10-2020; Accepted: 06-11-2020; Published 14-12-2020

Muhammad Abrar Parinduri*)
Universitas Medan Area
E-mail: abrarparinduri@staff.uma.ac.id

\section{Umi Kultsum}

Universitas Islam Negeri Sultan Maulana Hasanuddin-Banten

E-mail: Umi.kultsum@uinbanten.ac.id

\begin{abstract}
Empathy is the ability to understand the problems and feelings of others, to think from other people's points of view, and to be able to appreciate the differences in the feelings of others in response to various problems. The focus of this research lies in how the efforts to instill the values of empathy carried out by the Private Madrasah Aliyah Muhammadiyah-12 Punggulan of Asahan Regency in the midst of the Covid-19 pandemic. This research uses qualitative methods with field studies and literature studies. The results showed that the inculcation of the value of empathy in students was carried out in a motivational and planned way. The efforts made to instill the values of empathy include: First, the cultivation of the value of compassion for the meaning of life; Second, Friday blessings and the spirit of sharing; Third, be wise in using social media; Fourth, economic mapping of students' families as a form of madrasah empathy. The steps taken to make it happen are: First, the role model of the madrasa principal and teachers; Second, always provide motivation to students; Third, supervise students in using social media; Fourth, encourage students to carry out useful activities while studying at home, especially through the midnight prayer program at home only.
\end{abstract}

\begin{abstract}
Abstrak: Empati merupakan suatu kemampuan dalam memahami masalah dan perasaan orang lain, berpikir dengan menggunakan sudut pandang orang lain, serta mampu menghargai perbedaan perasaan orang lain dalam menanggapi berbagai masalah. Fokus penelitian ini terletak pada bagaimana upaya penanaman nilai-nilai empati yang dilakukan Madrasah Aliyah Swasta Muhammadiyah-12 Punggulan Kabupaten Asahan di tengah kondisi pandemic covid-19. Penelitian ini menggunakan metode kualitatif dengan studi lapangan dan studi kepustakaan. Hasil penelitian menunjukkan bahwa penanaman nilai empati pada siswa dilakukan cara memotivasi dan juga terencana. Upaya yang dilakukan untuk menanamkan nilai-nilai empati tersebut antara lain: Pertama, penanaman nilai welas-asih untuk kebermaknaan hidup; Kedua, jum'at berkah dan semangat berbagi; Ketiga, bijak dalam penggunaan media sosial; Keempat, pemetaan ekonomi keluarga siswa sebagai wujud empati madrasah. Adapun langkah-langkah yang dilakukan untuk mewujudkannya adalah: Pertama, keteladanan dari kepala
\end{abstract}


madrasah dan para guru; Kedua, senantiasa memberikan motivasi kepada siswa; Ketiga, melakukan pengawasan terhadap siswa dalam menggunakan media sosial; Keempat, mendorong siswa untuk melakukan aktifitas yang bermanfaat selama belajar di rumah khususnya melalui program sholat tahajjud di rumah saja.

Keywords: Islamic Education, Character Education and Empathy

\section{PENDAHULUAN}

$\mathrm{P}$ andemi covid-19 yang meluluhlantakkan sendi perekonomian dan moral bangsa tidak hanya terjadi di Indonesia, namun juga terjadi di berbagai belahan dunia. Virus corona merupakan jenis baru dari corona virus yang menular ke manusia. Virus ini menyerang manusia melalui sistem pernafasan. Penyakit yang ditimbulkan bilamana terkena oleh virus ini dinamakan covid-19. Selain gangguan terhadap pernafasan, virus Corona juga dapat menyebabkan pneumonia akut, sampai dengan kematian. Bangsa Indonesia tengah menghadapi virus ini sejak Maret 2020 hingga sekarang. Aktifitas lembaga pendidikan diminta untuk melaksanakan proses belajar mengajar dengan menggunakan sistem daring. Begitu juga dengan perkantoran yang bertugas melakukan pelayanan jasa terhadap masyarakat diminta untuk menerapkan protokol kesehatan agar mampu meminimalisir penyebaran virus tersebut.

Kondisi pandemi covid-19 memaksa semua pihak khususnya pengajar ataupun peserta didik agar mampu menggunakan teknologi digital sebagai tuntutan untuk mencerdaskan kehidupan anak bangsa. Namun dampak positifnya adalah bagi peserta didik semakin termotivasi untuk mengeksplorasi teknologi dan informasi, kemudian kreatifitas tersebut disalurkan melalui inovasi-inovasi ke dalam tugas yang diberikan.

Musibah covid-19 tidak boleh merobek persaudaraan antar manusia terlebih lagi persaudaraan yang diikat oleh rasa nasionalisme (bertanah air satu-tanah air Indonesia). Dalam relasi sosial, setidaknya ada 2 (dua) sentimen yang bisa dibedakan yakni: Pertama, sentimen sosial yang mengikat hubungan seseorang dengan orang lain sebagai sesama warga (anggota kelompok). Wujud implementasinya di dalam komunitas, yakni hubungan hidup (antar-individu) sehari-hari dan level relasi ini masuk pada ranah profan. Kedua, sentimen sosial yang biasa disebut dengan relasi sosial atau hubungan entitas sosial secara keseluruhan (menghubungkan antara satu komunitas dengan komunitas lainnya). Pada tahapan ini, sifat kedirian manusia ditarik secara keseluruhan dan yang muncul ke permukaan adalah kepentingan kolektif yang dibalut oleh rasa kemanusiaan hingga memunculkan rasa empati.

Empati merupakan instrumen untuk mengetahui dan berhubungan dengan orang lain serta di dalamnya dapat menambah kualitas hidup maupun interaksi sosial individu. Empati memiliki peran penting terhadap perkembangan individu dalam pemahaman sosial serta perilaku sosial yang positif sekaligus berfungsi sebagai landasan yang menjadi hubungan dasar koping stress serta penyelesaian konflik (Barr \& Higgins, 2009). Empati juga dapat dirasakan dalam kearifan lokal yang dimiliki suku bangsa di Indonesia. Dalam kebudayaan hidup orang Jawa misalnya, bagi mereka kebudayaan masa lampau mengajarkan masyarakat untuk saling menghargai dan mengutamakan tata krama. Setiap anggota kelompok hendaknya dapat mengembangkan keutamaan hidup seperti welas-asih (belas kasih), urip iku urup (hiduplah dengan memberi manfaat pada orang lain), ataupun memayu hayuning bawono (menjaga keharmonisan alam semesta) (Asep, 2010: 27).

Sikap empati tidak boleh hilang dalam identitas masyarakat modern. Sebagaimana diketahui bahwa masyarakat modern telah kehilangan dimensi kemanusiaannya. 
Manusia modern menjadi budak bagi mesin seperti komputer, internet, tablet, ipad dan semua peralatan komunikasi canggih lainnya yang serba otomatis sehingga dapat membuat masyarakat modern menjadi apatis terhadap kondisi lingkungannya. Segala kebaikan tampak mulai kehilangan makna seperti kepekaan sosial, kasih sayang, saling menghormati dan semua hal yang bersifat menyentuh suara hati dianggap sesuatu yang kosong tanpa makna (Hidayat, 2013: 172). Seruan kebaikan seperti perdamaian abadi, menjaga perdamaian dunia, memelihara lingkungan, bagaikan dongeng menjelang tidur. Tidak ada kedalaman makna terhadap setiap perbuatan (Zulkarnaen, 2018). Normanorma tradisional ditabrak semaunya, dan diganti dengan norma baru yang serba asing. Akhlak mulia kini dianggap perkataan usang dan kuno, maka dicarilah pengganti yang lebih canggih dan modern yakni gaya hidup bebas nilai yang meng-aminkan semua perbuatan atau perilaku manusia tanpa ada larangan, dan ironisnya itu pula yang dikatakan sebagai bagian dari kebahagiaan (Kurnia et al., 2020).

Beragam perdebatan yang disuguhkan melalui televisi, media sosial lainnya hampir setiap hari menyuguhkan ujaran kebencian (baik berbentuk penghinaan, menghasut, penistaan, perbuatan tidak menyenangkan, pencemaran nama baik hingga hoax/ berita bohong). Dalam kondisi ini pada akhirnya nilai kebenaran menjadi sesuatu yang dangkal (post-truth). Jean Baudrillard mengatakan bahwa perhatian dan konsentrasi manusia kini ditarik keseluruhannya ke dalam sebuah mandala (Medan) layaknya black hole. Ia menyebutnya dengan istilah Simulacra, yaitu suatu realitas baru yang disebut realitas maya, realitas semu, atau realitas buatan (hyper-reality). Akhirnya nilai keadaban dan kemanusiaan tercerabut dari akarnya serta nyaris tenggelam dalam riuhnya dunia digital yang penuh kebenaran dangkal (post-truth) akibat penyederhanaan masalah yang sesungguhnya memerlukan perhatian amat mendalam (McComiskey, 2017).
Menghadapi dinamika tersebut, seharusnya pendidikan Islam tetap mampu bertahan di tengah gempuran pergeseran nilai-nilai akhlak mulia. Pendidikan Islam adalah pendidikan manusia seutuhnya yakni akal dan hatinya, rohani dan jasmaninya, akhlak dan keterampilannya, sehingga pendidikan Islam diharapkan mampu menyiapkan manusia untuk tetap menghidupkan nilai keislamannya meskipun dalam keadaan damai maupun perang, dan menyiapkannya masyarakat untuk mampu menghadapi segala kebaikan dan kejahatan (Nizar, 2002). Pendidikan Islam sesungguhnya lebih banyak diarahkan dan ditujukan kepada proses perbaikan sikap mental yang akan terwujud dalam amal perbuatan baik bagi kebutuhan secara individu, maupun kebutuhan terhadap orang lain, sehingga pendidikan Islam tidak hanya berada pada tataran teoritis saja tetapi juga tataran praktis (Daradjat, 2008).

Dalam keterasingan manusia, ditambah riuhnya persoalan terbaru akibat pandemi covid-19, apresiasi setinggi-tingginya layak disampaikan kepada masyarakat Indonesia bahwa di tengah pandemi yang sedang menyelimuti negeri, survey terbaru Etnomark Consulting menyatakan bahwa 70 $\%$ masyarakat Indonesia ternyata masih memiliki perilaku sosial yang tinggi dan peduli terhadap orang lain. Sedangkan $27 \%$ masyarakat Indonesia masih berperilaku positif namun lebih mementingkan diri sendiri, dan hanya ada $3 \%$ masyarakat Indonesia yang memiliki perilaku egocentric. Survey ini dilakukan selama 3 minggu di bulan Maret 2020 melalui penelusuran akun media sosial dan hastag yang sedang trend seputar covid-19 (Munawaroh, 2020). Kondisi ini membawa angin segar bahwa nalar keadaban dan kemanusiaan masyarakat Indonesia patut untuk dibanggakan. Pada tahapan inilah semaian nilai empati menjadi sesuatu hal yang sangat berarti khususnya bagi mereka yang terkena dampak langsung maupun tidak langsung pandemi covid-19. 
Penelitian terkait empati dilakukan oleh (Valente, 2016) yang mengatakan bahwa individu dapat belajar berkomunikasi secara lebih efisien dan efektif dengan mengembangkan empati dalam diri mereka sendiri maupun orang lain. Ada empat tema internal terkait pemahaman empati yang meningkat dalam penelitian ini yakni: berbagi emosi, hubungan positif, saling menghargai, dan keaslian pribadi. Ada tiga tema eksternal yang memoderasi kekuatan atau arah persepsi empati mereka yakni kesamaan yang dirasakan, relevansi, dan ketersediaan orang yang diamati.

Dari beberapa hasil penelitian di atas, menurut peneliti sikap empati menjadi hal yang sangat mendesak untuk ditanamkan kepada warga sekolah maupun semua orang. Sikap dan karakter ini akan menjadi cerminan dari masa depan sebuah bangsa. Dari sikap empati ini akan menjadikan manusia hidup lebih harmonis, dengan empati diharapkan mereka lebih toleransi untuk saling menghargai setiap perbedaan yang ada serta enggan untuk saling melukai antara satu dengan lainnya. Penelitian ini mengungkapkan bagaimana pendidikan Islam khususnya di Madrasah Aliyah Swasta (MAS) Muhammadiyah-12 Punggulan Kabupaten Asahan berupaya menamamkan nilai empati kepada para siswa dan warga sekolah secara keseluruhan di tengah kondisi covid-19. Apa saja bentuk konkrit yang dilakukan untuk penanaman sikap empati tersebut serta bagaimana cara madrasah mewujudkannya.

\section{METODE PENELITIAN}

Penelitian ini menggunakan metode kualitatif dengan studi lapangan dan studi kepustakaan (library research). Metode kualitatif digunakan untuk memperoleh pemahaman mendalam terhadap indikator jawaban khususnya yang berkaitan dengan sikap empati warga sekolah di tengah kondisi pandemi covid-19. Objek penelitian ini adalah Madrasah Aliyah Swasta (MAS) Muhammadiyah-12 Punggulan Kabupaten Asahan. Penelitian dilaksanakan pada tanggal 26-30 Juni 2020. Adapun sumber data utama (primer) dalam penelitian ini diperoleh melalui penelitian lapangan (field research) melalui wawancara via daring, observasi terhadap media sosial dan studi dokumen (kebijakan atau peraturan sekolah). Sedangkan data sekunder diperoleh dari bahan-bahan pustaka yang berkaitan dengan sikap empati yang tersebar di banyak literatur seperti buku-buku ataupun artikel yang otoritatif.

Guna mendapatkan pemahaman yang lebih luas dan mendalam terhadap situasi yang diteliti, maka teknik pengumpulan data yang digunakan adalah wawancara, observasi, dan studi dokumen. Adapun teknik wawancara yang digunakan adalah wawancara semi terstruktur. Wawancara dilakukan dengan kepala madrasah, guru bidang studi agama, wali kelas, dan ketua kelas, serta beberapa siswa. Wawancara dilakukan bertujuan guna memperoleh informasi terkait kebijakan sekolah, metode pembelajaran, proses belajar mengajar serta interaksi sosial yang mendukung terciptanya sikap empati antar siswa dan warga sekolah selama pandemi covid-19.

Dikarenakan kondisi pandemi covid-19 maka tidak semua wawancara dapat dilakukan secara langsung. Wawancara yang dilakukan secara langsung antara lain kepada kepala madrasah, guru bidang studi agama, wali kelas, dan beberapa orang guru. Serta wawancara melalui jaringan media sosial dilakukan kepada ketua kelas, serta beberapa siswa. Selanjutnya observasi dilakukan pada media sosial sekolah dan group antar siswa maupun guru yang mendukung lahirnya sikap empati. Sedangkan studi dokumen digunakan untuk menggali data dalam bentuk dokumen-dokumen penting yang berkaitan kebijakan dan peraturan sekolah selama masa pandemi.

\section{HASIL DAN PEMBAHASAN \\ Urgensi Empati pada Lembaga Pendidikan}

Menurut Golleman (1996), empati merupakan suatu kemampuan dalam 
memahami masalah dan perasaan orang lain, berpikir dengan menggunakan sudut pandang orang lain, serta mampu menghargai perbedaan perasaan orang lain dalam menanggapi berbagai masalah. Empati merupakan kemampuan untuk meletakkan diri sendiri dalam posisi orang lain dan berusaha menghayati pengalaman di dalamnya untuk melihat sebuah permasalahan dari sudut yang berbeda. Secara sederhana dapat dikatakan bahwa empati merupakan kemampuan menghayati perasaan dan emosi orang lain. Empati dalam nilai budaya lokal Minangkabau terdapat dalam pepatah yakni marangkuah tungua $k a$ dado, maraiah suatu $k a$ diri yang artinya setiap suatu yang dirasakan oleh orang lain hendaknya dapat dirasakan oleh diri sendiri (Mas'oed Abidin, 2004).

Masih berkaitan tentang empati, Davis mendefenisikan empati merupakan kemampuan memproyeksikan perasaan diri sendiri pada suatu kejadian, pengertian terhadap kebutuhan dan penderitaan orang lain. Secara singkat empati adalah mampu merasakan emosi orang lain baik secara fisiologis maupun mental ataupun semakin sama keadaan fisiologis 2 (dua) individu pada momen tertentu, maka semakin mudah bagi mereka untuk merasakan persaan antara satu dengan lainnya (empati) (Davis, 1983).

Sebagai bagian dari kecerdasan emosional, maka Golleman (1996) membagi ciri-ciri kemampuan empati menjadi 3 (tiga) yakni: Pertama, mampu mendengarkan pembicaraan orang lain dengan baik; artinya seorang individu harus mampu memberi perhatian dan menjadi pendengar yang baik untuk segala permasalahan yang diungkapkan orang lain kepada dirinya. Kedua, mampu menerima sudut pandang orang lain; artinya dalam memandang permasalahan orang lain, individu menempatkan dirinya pada orang tersebut sehingga diharapkan muncul toleransi dan kemampuan menerima segala perbedaan. Ketiga, memiliki kepekaan terhadap perasaan orang lain; artinya individu mampu membaca perasaan orang lain hanya dari isyarat verbal maupun non-verbal seperti nada bicara, bahasa tubuh, gerak-gerik, dan ekspresi wajah.

Pengalaman masa lalu, seringkali menjadi pedoman bagi orang lain dalam mengungkapkan reaksi empati. Dari perbedaan pengalaman ini pada akhirnya memunculkan reaksi empati yang berbeda pula. Golleman (D. Golleman, 1996) membagi ciri orang yang memiliki empati tinggi antara lain: Pertama, kemampuan ikut merasakan perasaan orang lain (sharing feeling). Kedua, orang yang berempati tinggi adalah memiliki kesadaran diri yang kuat. Ketiga, orang yang berempati tinggi adalah mereka yang memiliki inisiatif untuk mengambil peran (role taking) sehingga diharapkan lahir perilaku empati yang konkrit. Keempat, orang yang memiliki empati tinggi adalah mereka yang mampu mengendalikan emosinya ketika sedang berempati.

Perkembangan teknologi saat ini ditambah munculnya wabah pandemi covid19 semakin membuat invidu terasing dari lingkungan sosialnya yang berakibat terhadap memudarnya budaya empati kepada orang lain. Jika persoalan ini diabaikan terlalu lama maka dapat menyebabkan seseorang menjadi pribadi yang anti sosial. Apabila perilaku prososial dalam diri individu (siswa) terus berkurang maka akan berpengaruh negatif pada diri individu tersebut (Yoo, Feng, \& Day, 2013).

Berdasarkan hasil wawancara dengan kepala Madrasah, Izhar Fuadi Lubis mengatakan bahwa pada akhir bulan Maret 2020, rasa khawatir terhadap perubahan sikap siswa mulai menjadi bahan diskusi dari para guru dan juga komite Madrasah. Dengan kondisi siswa belajar dari rumah tanpa berinteraksi secara langsung dengan guru maupun teman-temannya dikhawatirkan menyebabkan para siswa memiliki sikap anti sosial. Jika kondisi ini dibiarkan begitu saja tanpa ada inisiatif dari pihak Madrasah dalam melakukan inovasi pembelajaran, maka bukan hanya sikap anti sosial yang akan muncul melainkan angka putus sekolah 
juga dikhawatirkan menjadi ancaman berikutnya.

Sembari memikirkan solusi apa yang tepat untuk melakukan inovasi pembelajaran, ide cemerlang datang dari siswa yakni dengan melebarkan cakupan program Jum'at berkah yang memang sudah ada sejak bulan Agustus 2019. Program Jum'at berkah yang selama ini hanya diperuntukkan bagi warga sekitar sekolah, kini diperluas cakupannya dengan melibatkan para donatur dari luar agar hasil yang diperoleh juga bertambah banyak dan pendistribusiannya bukan hanya untuk warga sekolah melainkan juga warga lain yang layak untuk menerima bantuan sembako. Agar distribusi dilakukan tepat sasaran, pihak madrasah melibatkan unsur kepala lingkungan yang lebih mengetahui kondisi warganya.

Ide berbeda berikutnya datang dari guru bidang studi Akidah Akhlak yakni terkait pelaksanaan Sholat Tahajjud di rumah namun pelaksanaannya dipantau oleh 3 (tiga) guru bidang studi sekaligus yakni guru bidang studi Akidah Akhlak, guru bidang studi Al Islam dan Kemuhammadiyahan, serta guru Qur'an Hadis. Program sholat Tahajjud di rumah di tengah kondisi pandemi covid-19 adalah ihtiar dari pihak madrasah untuk meminimalisir rasa bosan dan sikap anti sosial pada diri siswa. Izhar Fuadi Lubis menyadari bahwa memberikan pengetahuan kognitif saja kepada siswa tidak akan cukup untuk menumbuhkan sikap peduli pada diri siswa namun harus dibantu melalui pendidikan spritual yakni dengan melaksanakan program sholat Tahajjud di rumah.

Salah satu usaha penanaman nilai-nilai empati yang dilakukan Madrasah Aliyah Swasta (MAS) Muhammadiyah-12 Punggulan Kabupaten Asahan kepada siswasiswi adalah melalui 2 (dua) konsep empati yakni: Pertama, empati yang dilihat berdasarkan persepsi orang lain. Pada tahapan ini dapat diartikan bahwa seorang individu harus mengerti dan memahami bagaimana orang lain berpikir dalam keadaan yang dialaminya. Kedua, memahami orang lain secara mendalam yang artinya individu seolah-olah menjadi bagian dari diri orang lain. Pada kondisi ini diharapkan akan muncul perasaan empati dan individu dapat menghayati perasaan orang lain. Berdasarkan penjelasan tersebut, maka dapat diambil kesimpulan bahwa empati adalah usaha untuk memahami perasaan orang lain secara emosional dan berusaha menempatkan diri seolah-olah menjadi bagian tersebut agar dapat merasakan apa yang dialaminya dan membantu menyelesaikan masalahnya (Silfiasari \& Prasetyaningrum, 2017).

\section{Internalisasi Nilai Empati pada Warga Sekolah}

Sebelum pandemi covid-19 terjadi, pembelajaran di Madrasah Aliyah Swasta (MAS) Muhammadiyah-12 Punggulan Kabupaten Asahan berjalan sebagaimana biasanya. Dikarenakan Madrasah ini berdomisili dekat dengan pemukiman penduduk yang sebagiannya bermata pencaharian petani, tentu ekspektasi masyarakat dan peserta didiknya berbeda jauh dengan sekolah yang berada di perkotaan dengan multi profesi. Biasanya para siswa yang bersekolah di wilayah perkotaan memiliki cita-cita yang tinggi dengan ragam profesi yang diinginkan. Namun sebaliknya, para siswa yang bersekolah di wilayah pedesaan cenderung tidak berlebihan dalam memposisikan dirinya. Para siswa yang mengenyam bangku sekolah di wilayah pedesaan pada umumnya merasa bersyukur jika sudah mampu menyelesaikan sekolahnya dengan baik. Terlebih lagi para siswa-siswi yang berada di Madrasah Aliyah Swasta (MAS) Muhammadiyah-12 Punggulan Kabupaten Asahan ini, hanya $20 \%$ siswa yang menyatakan ingin melanjutkan kuliah, dan sisanya merasa puas hanya dengan tamat sekolah dengan menjadi guru ngaji, atau menggantikan pekerjaan orangtuanya sebagai petani.

Sebagai kepala madrasah yang baik, Izhar Fuadi Lubis tetap memberi motivasi kepada anak didiknya agar mampu 
melanjutkan ke jenjang yang lebih tinggi setelah tamat dari Madrasah Aliyah yakni kuliah di Kota Medan atau kuliah di kampus yang berada di wilayah Kabupaten Asahan. Bagi kepala madrasah, kemampuan untuk mengenyam bangku perkuliahan hari ini tidak hanya dapat dinikmati oleh para siswa yang berasal dari kalangan keluarga kaya raya namun semua orang hari ini memiliki kesempatan yang sama untuk mengenyam bangku kuliah dan yang membedakan mereka adalah statusnya yakni beasiswa atau biaya sendiri. Pemerintah telah banyak menyediakan program beasiswa seperti bidik misi, dan lainnya maka semuanya berpulang kepada siswa tersebut. Jika memiliki prestasi namun berlatar belakang ekonomi keluarga yang tidak mampu, raihlah beasiswa tersebut dengan cara berkompetisi yang baik dimulai dengan belajar giat dan sungguh-sunguh. Namun jika keluarga memiliki kemampuan kepada anaknya untuk mengenyam bangku kuliah, maka manfaatkan momentum itu dengan sebaik-baiknya. Temuan ini relevan dengan dengan penelitian yang dilakukan oleh Munir \& Hartono (2016) yang menyatakan bahwa pendidikan formal mesti mengajarkan kepedulian lingkungan (environmental awareness) dan kepedulian sosial (social awareness) sebagai bentuk implementasi nilai karakter yang sudah dicanangkan Menteri Pendidikan Nasional.

Selain memotivasi para siswa untuk gigih dalam belajar, kepala madrasah juga senantiasa memberi nasehat kepada peserta didiknya untuk hiduplah dengan memberi manfaat kepada orang lain. Karena Madrasah Aliyah Swasta (MAS) Muhammadiyah-12 Punggulan Kabupaten Asahan berada di sekitar pemukiman penduduk yang mayoritasnya suku Jawa maka filosofi urip $i k u$ urup menjadi akrab dalam keseharian mereka. Bagi kepala madrasah, siswa yang berhasil bukan hanya ditentukan oleh nilai mata pelajaran, akan tetapi yang lebih penting adalah memiliki etika atau moral yang baik (Komariah, 2017).
Menciptakan siswa dengan moral yang baik tentu bukanlah pekerjaan mudah, oleh karena itu kepala madrasah menyatakan bahwa ini adalah kerja besar dan harus dilakukan secara bersama-sama. Baginya dukungan semua warga sekolah dimulai dari guru, kemudian masyarakat sekitar, kesadaran siswa, dan dukungan keluarga siswa menjadi modal yang kuat untuk melahirkan siswa-siswi yang berakhlak mulia. Tidak ada pengorbanan tanpa kerja keras dan hasil tidak akan pernah mengkhianati usaha yang dilakukan oleh manusia. Apa yang dilakukan oleh kepala madrasah sejalan dengan yang dikemukakan Golleman terkait ciri orang yang memiliki empati tinggi yakni kemampuan untuk memahami atau merasakan emosi dan perasaan orang lain (D. Golleman, 1996).

\section{Penanaman Nilai Welas-Asih untuk Kebermaknaan Hidup}

Disamping mengamalkan kebermaknaan dalam hidup, kepala madrasah juga mengajarkan kepada seluruh warga sekolah untuk senantiasa merawat welas-asih (belas kasih). Budaya welas-asih sangat diperlukan dalam kondisi apapun karena manusia dalam kehidupannya tidak mungkin hidup tanpa membutuhkan bantuan atau pertolongan orang lain. Dari sikap welas-asih diharapkan akan mampu melahirkan sikap empati dan berujung pada empati. Sikap empati dalam era globalisasi sekarang ini menjadi sesuatu yang sangat langka karena manusia yang hidup di zaman modern cenderung individualis dan hanya mementingkan diri sendiri. Upaya menanamkan sikap empati pada siswa-siswi Madrasah Aliyah tidak hanya sekedar nasehat melainkan harus ada aksi nyata karena pengalaman adalah guru terbaik bagi manusia. Dalam hal menanamkan empati kepada siswa-siswi, kepala madrasah beserta para guru (khususnya wali kelas), mereka selalu mengajarkan kepada siswa-siswi yang telah lulus untuk tidak merayakan kelulusan dengan cara yang hura-hura seperti mencoret baju sekolah. Yang diajarkan kepada mereka adalah menyisihkan baju sekolah yang layak 
dipakai untuk kemudian diberikan kepada orang-orang yang membutuhkan.

\section{Jumat Berkah dan Semangat Berbagi}

Selain kebiasaan di atas, sekolah juga mengajarkan kepada siswa-siswinya untuk menyisihkan sebagian rezeki setiap Jumat yang dinamakan program Jumat Berkah. Program ini bertujuan untuk menanamkan semangat berbagi sejak dini kepada para siswa agar nantinya setiap libur akhir semester melalui dana yang sudah terkumpul dari program Jumat Berkah, kemudian diserahkan kepada masyarakat sekitar sekolah (yang tidak mampu) dalam bentuk sembako dengan harapan semua warga sekolah mendapat doa dari warga tersebut agar senantiasa memperoleh kemudahan dan keberkahan hidup. Program Jumat Berkah ini sudah berjalan sejak Agustus 2019 dan sampai sekarang menjadi program khas Madrasah Aliyah Swasta (MAS) Muhammadiyah-12 Punggulan Kabupaten Asahan. Sejak program ini digulirkan, terkadang selalu ada donatur yang menitip sebagian rezekinya kepada madrasah untuk kemudian nantinya disalurkan secara bersamaan melalui program Jumat Berkah.

Senada dengan ungkapan kepala madrasah, ketua kelas XI membenarkan hal tersebut bahwa di Madrasah Aliyah Swasta (MAS) Muhammadiyah-12 Punggulan Kabupaten Asahan, ia mendapat pengalaman yang berbeda dari sekolah pada umumnya. Sejak mengenyam bangku pendidikan di Madrasah ini, dirinya mulai menyadari pentingnya berbuat kebaikan pada orang lain terlebih-lebih sesama teman. Terkadang muncul keinginan dalam hati untuk turut merasakan bagaimana sensasi mencoret baju sewaktu merayakan penyelesaian Ujian Akhir Nasional, namun ia pun selalu teringat nasehat yang disampaikan oleh kepala madrasah tentang pentingnya memiliki kepribadian dan akhlak mulia serta senantiasa memperhatikan setiap perbuatan yang dilakukan (bermanfaat atau tidak). Menurut ketua kelas XI, sebagai siswa Madrasah yang identik dengan kemampuan pemahaman agama mumpuni, maka dirinya merasa punya beban moral untuk selalu tampil lebih baik dari segi moral dan etika daripada siswa-siswi yang mengenyam bangku di sekolah umum. Apa yang dilakukan oleh siswa-siswi tersebut sejalan dengan yang diungkapkan oleh Golleman terkait individu yang memiliki empati tinggi yakni kemampuan membangun kesadaran diri yang artinya semakin terampil ia membaca dan memahami perasaan atau emosi orang lain maka semakin banyak ia menaruh belas kasihan dan pada akhirnya individu tersebut bersedia membantu orang lain (Golleman, 1996).

Terkait program Jumat Berkah, ketua kelas X membenarkan bahwa di Madrasah Aliyah Swasta (MAS) Muhammadiyah-12 Punggulan Kabupaten Asahan terdapat program tersebut. Program Jumat Berkah bagi dirinya membawa pengalaman baru tentang pentingnya semangat berbagi pada orang lain. Baginya, menyisihkan sebagian rezeki kepada orang yang membutuhkan sangat identik dengan ciri dari Mukmin yang sesungguhnya. Hal senada juga dibenarkan oleh guru mata pelajaran Qur'an Hadits bahwa program Jumat Berkah kini menjadi penciri bagi Madrasah Aliyah Swasta (MAS) Muhammadiyah-12 Punggulan Kabupaten Asahan. Tak heran, menurutnya banyak orang yang mulai simpati terhadap keberadaan Madrasah ini dikarenakan perhatian yang kami berikan terhadap masyarakat sekitar (khususnya mereka yang tergolong orang tidak mampu). Menurut sang guru, kami hanya berharap doa tulus dari mereka, agar Madrasah Aliyah Swasta (MAS) Muhammadiyah-12 Punggulan Kabupaten Asahan menjadi Madrasah yang mampu melahirkan generasi Muslim yang tidak hanya saleh secara individu melainkan juga saleh secara sosial.

\section{Bijak dalam Penggunaan Media Sosial}

Adapun terkait komitmen untuk bijak dalam penggunaan media sosial, kepala madrasah tidak memiliki program khusus namun senantiasa bekerjasama dengan para guru lainnya untuk memantau aktifitas siswa dalam bermedia sosial. Ada beberapa guru 
yang mendapat tugas khusus dari kepala madrasah untuk membuat akun samaran di media sosial agar keberadaan sang guru tidak diketahui oleh siswa. Cara ini menurutnya sangat efektif dalam memantau aktifitas siswa-siswinya dalam penggunaan media sosial. Peristiwa kerusuhan bernuansa sara di Tanjung Balai yang terjadi pada Juli 2016 (Sitorus, 2019) membuat kepala madrasah beserta para guru perlu mengambil sikap tegas dan hati-hati agar para siswanya tidak terlibat dalam penyebaran berita tersebut yang dapat memicu pertikaian umat beragama. Kepala Madrasah menyatakan bahwa peristiwa bernuansa sara di Tanjung Balai pada Juli 2016 sangat membuat dirinya merasa khawatir jika persitiwa tersebut melebar hingga ke Kabupaten Asahan mengingat Kota Tanjung Balai dengan Kabupaten Asahan adalah tetangga (saling berdekatan).

\section{Pemetaan Ekonomi Keluarga Siswa sebagai Wujud Empati Madrasah}

Selain memantau secara tidak langsung terkait penggunaan media sosial oleh siswasiswinya, kepala madrasah juga menyatakan bahwa ketika pembelajaran daring mulai diberlakukan untuk mengantisipasi penyebaran pandemi covid-19, dirinya bersama dengan para guru yang lain juga mengajak para siswa untuk membangun kepedulian saat pandemi dengan berbagai macam aktifitas diantaranya adalah turut memantau secara tidak langsung perekonomian keluarga siswa bilamana ada diantaranya yang terkena dampak langsung musibah covid-19. Meskipun mayoritas mata pencaharian penduduk sekitar madarasah adalah petani, namun sektor ini juga mengalami dampak dari musibah covid-19. Dari pemantauan yang dilakukan kepala madrasah bekerjasama dengan para guru dan siswa, akhirnya di dapat satu orang siswa yang terancam putus sekolah. Berawal dari Putri (nama samaran) siswi kelas XI yang tidak memberi kabar terkait pengumpulan tugas mata pelajaran Matematika, memaksa sang guru sekaligus wali kelas XI untuk mencari tahu apa yang sesungguhnya terjadi pada diri siswa tersebut. Setelah mencari tahu selama hampir 1 (satu) minggu akhirnya sang guru mengetahui bahwa orangtua Putri merupakan tenaga kerja di Malaysia dengan jenis pekerjaan sebagai pelayan di salah satu rumah makan tepatnya di Negeri Sembilan Malaysia.

Saat covid-19 terjadi, rumah makan tempat orangtua Putri bekerja tidak lagi memperpanjang kontrak para karyawannya dikarenakan pengunjung yang mulai sepi akibat covid-19 sehingga berdampak langsung terhadap kemampuan perusahaan untuk membayar gaji karyawan. Awal Mei 2020 orangtua Putri terpaksa kembali ke Indonesia, dan tentu berakibat langsung terhadap perekonomian keluarga. Putri adalah anak kedua dari tiga bersaudara. Dari peristiwa ini, sang guru berkoordinasi dengan kepala madrasah untuk mengambil kebijakan yang tepat agar siswi tersebut jangan sampai putus sekolah. Akhirnya melalui rapat antara kepala madrasah dengan guru diambil kesepakatan untuk melakukan pemetaan terhadap perekonomian keluarga siswa dengan 3 (tiga) kategori yakni baik, kurang baik, dan prihatin. Untuk kategori tingkat ekonomi keluarga yang kurang baik, madrasah memberi keringanan berupa pengurangan infak sekolah $25 \%$, sedangkan untuk tingkat ekonomi keluarga yang prihatin, madrasah menetapkan pengurangan infak sekolah $50 \%$. Kebijakan ini mulai berlaku sejak Juni 2020 hingga batas waktu yang belum ditentukan. Tidak hanya kepada siswa-siswi lama, untuk penerimaan peserta didik yang baru, kepala madrasah beserta para guru juga membuat kebijakan untuk membebaskan iuran infak sekolah hingga covid-19 dinyatakan selesai oleh pemerintah.

\section{Empati Siswa: Dari Teori Hingga Aksi Nyata}

Disamping kebijakan madrasah yang memberi keringanan terhadap iuran infak mahasiswa, ternyata beberapa siswa juga berinisiatif untuk membantu temannya yang sedang mengalami kesusahan. Menurut keterangan kepala madarasah, sejak akhir Mei 2020 beberapa siswanya ada yang 
berjualan masker dan hand-sanitizer di dekat SPBU (sekitar $3 \mathrm{~km}$ dari madrasah). Kepala Madrasah mengetahui hal tersebut melalui guru yang ditugaskan memantau akfititas anak-anak dalam menggunakan media sosial. Yang menarik dari aktifitas mereka menurut kepala madrasah adalah bahwa sebagian keuntungan dari hasil penjualan masker dan hand-sanitizer itu akan digunakan untuk membantu teman-temannya yang sedang mengalami kesulitan ekonomi dalam keluarga. Menurut kepala madrasah, para siswanya sudah mengamalkan sikap kepedulian yang terbaik kepada temantemannya yang dalam bahasa lain disebut juga dengan empati. Media jual-belinya juga tidak hanya manual namun menggunakan media sosial seperti Instagram, Faceboook, dan WAG. Empati menurut kepala madrasah adalah berusaha membangun kepedulian dan membantu orang lain baik secara langsung maupun melalui perantara orang lain atau dalam hal ini perantara dengan menggunakan media sosial.

Sembari memupuk dan merawat empati kepada para siswa, kepala madrasah juga menekankan pentingnya empati kepada antar sesama siswa maupun warga sekolah. Menurut kepala madrasah, dalam rangka mewujudkan rasa kepedulian atau empati di lingkungan Madrasah Aliyah Swasta (MAS) Muhammadiyah-12 Punggulan Kabupaten Asahan, maka khusus paket sembako yang akan dibagikan akhir bulan Juli 2020 melalui hasil program Jumat Berkah (yang kini selama covid-19 hanya mengandalkan para dermawan) untuk distribusinya diutamakan kepada keluarga para siswa yang tergolong tingkat ekonomi prihatin berdasarkan pemetaan pihak madrasah. Melalui penggalangan dana yang dilakukan kepala madrasah kepada para dermawan dan juga dibantu oleh guru-guru lainnya, mereka berharap hasil program Jumat Berkah yang akan dibagikan dalam bentuk sembako nantinya dapat memperoleh target yang signifikan. Musibah covid-19 menurut kepala madrasah jangan sampai menghilangkan rasa peduli terhadap sesama manusia terlebih lagi kepedulian pihak madrasah terhadap para siswa dan warga sekolah.

Empati lainnya yang dilakukan oleh pihak madrasah adalah menyatukan beberapa bidang studi agama khususnya al-Islam dan Kemuhammadiyahan, Quran Hadits, Akidah Akhlak ke dalam satu penilaian khusus yakni sholat tahajjud. Selama pandemi berlangsung, para siswa diminta melaksanakan sholat tahajjud di rumah dan pengawasannya akan dilakukan oleh guru bidang studi tersebut secara bergantian via WAG. Sholat tahajjud dilaksanakan para siswa minimal 2 (dua) kali dalam 1 bulan dan dilaksanakan setiap Sabtu malam di minggu ke-I dan ke-III. Menurut kepala madrasah, pilihan ini mereka lakukan agar karakter yang telah dibangun kepada diri para siswa tidak mudah terkontaminasi akibat lebih banyak waktu di rumah sekaligus menguatkan kesabaran pada diri siswa agar mampu menghadapi musibah covid-19 dengan aktifitas yang bermanfaat. Bagi kepala madrasah, penyatuan tiga bidang studi ini ke dalam satu penilaian adalah bentuk empati pihak madrasah terhadap para siswa. Jangan sampai siswa hanya mendapatkan dimensi kognitif saja namun dimensi kerohaniannyai tidak diperhatikan. Karena menurut kepala madrasah, yang paling rentan bagi siswa saat pandemi seperti ini adalah kekosongan dalam pembinaan rohani. Oleh karena itu, madrasah merasa berkepentingan untuk mengisi ruang kosong pada diri siswa dengan penanaman nilai religiusitas melalui sholat tahajjud di rumah.

Menurut kepala madrasah, penanaman nilai empati tidak hanya diarahkan pada diri siswa namun juga harus dimulai dari pucuk pimpinan tertinggi yakni kepala madrasah dan para dewan guru. Menanamkan nilainilai pendidikan yang terbaik pada diri siswa adalah melalui keteladanan. Jika guru tidak mampu memberi contoh teladan, maka mustahil siswa akan menuruti nasehat yang diberikan oleh gurunya. Namun jika guru sudah memberikan contoh teladan yang baik, meskipun siswa masih enggan mengikuti 
nasehat guru namun dapat dipastikan pada diri siswa terdapat rasa sungkan dan lambat laun siswa tersebut akan menjalankan nilainilai kebaikan yang telah diajarkan sang guru kepada dirinya. Bagi kepala madrasah, tantangan terberat dalam penanaman nilai karakter di lembaga pendidikan hari ini adalah kemampuan guru beradaptasi dengan kecanggihan teknologi dan berusaha untuk tampil survive tanpa harus meninggalkan jati diri sebagai seorang pendidik yang layak digugu dan ditiru oleh para siswanya. Senada dengan kepala madrasah, guru bidang studi Akidah Akhlak membenarkan bahwa diperlukan kearifan dan fleksibelitas sebagai seorang pendidik dewasa ini mengingat zaman yang sudah berbeda. Baginya tidak mungkin melarang para siswa dalam menggunakan teknologi seperti media sosial. Namun yang terpenting adalah pengawasan dari orangtua dan sekolah, agar para siswa menyadari bahwa mereka harus mampu mengendalikan teknologi dan bukan sebaliknya dikendalikan oleh teknologi.

\section{KESIMPULAN DAN REKOMENDASI}

Sebagai bagian dari lembaga pendidikan Islam, Madrasah Aliyah Swasta (MAS) Muhammadiyah-12 Punggulan Kabupaten Asahan merasa bertanggung jawab untuk memperhatikan karakter siswanya melalui penanaman nilai-nilai empati. Upaya untuk membangun nilai empati tersebut antara lain:

1. Penanaman nilai welas-asih untuk kebermaknaan hidup.

2. Program Jumat berkah dan semangat berbagi.

3. Bijak dalam penggunaan media sosial.

4. Pemetaan ekonomi keluarga siswa sebagai wujud empati madrasah.

Berbagai langkah yang dibutuhkan dalam penanaman nilai-nilai empati tersebut dilakukan dengan berbagai cara antara lain: Pertama, keteladanan dari kepala madrasah dan para guru; Kedua, senantiasa memberikan motivasi kepada siswa; Ketiga, melakukan pengawasan terhadap siswa dalam menggunakan media sosial; Keempat, mendorong siswa untuk melakukan aktifitas yang bermanfaat selama belajar di rumah khususnya melalui program sholat tahajjud di rumah saja. Kesemuanya ini dilakukan oleh Madrasah Aliyah Swasta (MAS) Muhammadiyah-12 Punggulan Kabupaten Asahan adalah semata-mata untuk menciptakan generasi emas 2045 sebagaimana yang termaktub dalam cita-cita pendidikan nasional.

\section{REFERENSI}

Asep, R. (2010). Falsafah Hidup Jawa. Yogyakarta: Logung Pustaka.

Barr, J. J., \& Higgins, A. (2009). "How Adolescent Empathy and Prosocial Behavior Change In The Context Of School Culture A Two-Year Longitudinal Study." Journal Adolescence, 44, 176.

D. Golleman. (1996). Kecerdasan Emosional. Jakarta: PT. Gramedia Pustaka Utama.

Daradjat, Z. (2008). Ilmu Pendidikan Islam. Jakarta: Bumi Aksara.

Davis, M. H. (1983). A Mulitdimensional Approach to Individual Differences in Empathy. Journal of Personality and Social Psychology, 44(1), 113-126. https://doi.org/10.1037/0022-

3514.44.1.113

Hidayat, K. (2013). Psikologi Kebahagiaan. Jakarta: Mizan.

Kokom Siti Komariah. (2017). Core Value (Ta'awun Value) in The Development Program of Inclusive Education. Jurnal Ta'dib IAIN Batusangkar, 20(2), 144154.

Mas'oed Abidin. (2004). Implementasi Adat Basandi Syarak, Syarak Basandi Kitabul-lah. Padang: Pusat Pengkajian Islam Minangkabau (PPIM)).

McComiskey, B. (2017). Post-Truth Rhetoric and Composition. Colorado: Utah State University Press.

Munawaroh, S. (2020). Survei: Mayoritas Masyarakat Indonesia Tetap Optimis \& Siap Membantu Saat Pandemi Covid19. 
Munir, M., \& Hartono, R. (2016). Islamic Magazine Articles to Enhance Students'reading Skill and Build Their Character Values. International Journal of Education, 9(1), 69-74.

Nizar, S. (2002). Filsafat Pendidikan Islam: Pendidikan Historis, Teoritis dan Praktis. Jakarta: Ciputat Pers.

Silfiasari, \& Prasetyaningrum, S. (2017). "Empati dan Pemaafan dalam Hubungan Pertemanan Siswa Regular Kepada Siswa Berkebutuhan Khusus (Abk) di Sekolah Inklusif." Jurnal Ilmiah Psikologi Terapan, 05(01).

Sitorus, J. (2019). "Majelis Buddhayana Indonesia Membangun Binadamai Antar Umat Beragama." Jurnal Ilmiah Sosial Agama, 2(1).

Ulfa, Kurnia, \& Heryadi, A. (2020). "Spiritual Intelligence And
Organizational Commitments Of PAC IPNU Magelang Regency." Psikis : Jurnal Psikologi Islami, 6(1), 58-67.

Valente, F. (2016). Empathy and Communication: A Model of Empathy Development. Journal of New Media and Mass Communication, 3(1), 1-24. https://doi.org/10.18488/journal.91/201 6.3.1/91.1.1.24

Yoo, H., Feng, X., \& Day, R. D. (2013). Adolescents' Empathy and Prosocial Behavior in the Family Context: A Longitudinal Study. Journal of Youth and Adolescence, 42(12), 1858-1872. https://doi.org/10.1007/s10964-0129900-6

Zulkarnaen, D. (2018). "Pancasila: Local Indigenous Islamic Character Education In Indonesia." Madania: Jurnal Kajian Keislaman [Online], 22(2). 